and Cryptolithinae. In Lower Cambrian Albertella helena Walcott (1908, pl. 2, fig. 5), however, the eye appears to arise from the rear of the second of the three pseudofrontal segments, and it also seems to be attached to this segment in Bathyuriscus ornatus Walcott (1908, pl. 1, fig. 1). In Neolenus inflatus Walcott (1908, pl.5, fig. 2), the eyeline originates well forward in the pseudofrontal lobe, and similarly with later members of the Olenidae. This line of evidence tends to contradict the customary view that the eyes in Mesonacidae and Olenidae are homologous.

On the question of the evolution of the trilobite hypostome, account should have been taken of E. D. Gill's treatment of it as representing former dorsal segments, and I hope that some of my opinions are complementary to his. Consideration of a genus like Phillibole R. and E. Richter (1949) makes me doubt whether one can dogmatize about a definite number of cephalic segments in trilobites retaining ancestral characters.

Grant Institute of Geology,

ARChIE LAMONT.

West Mains Road, EDINBURGH, 9.

27 th March, 1951.

\title{
REFERENCES
}

Austin, T., 1860. On the Lower Silurian Rocks in the South-East of Ireland ..."The Geologist, iii, 70-3.

GiLL, E. D., 1949. Descriptions and Biological Interpretation of some Victorian Trilobite hypostomes. Proc. R. Soc. Victoria, lxi (new series), 123-131.

LAMONT, A., 1939. Notes on Distribution and Migration of Brachionods in the British and Irish Lower Palaeozoic Faunas. Irish. Nat. Journ., vii, $172-8$.

- 1950. Cephalic Segmentation and Sutures in Trilobites. Geol. Mag., Ixxxvii, 300-1.

PortLock, J. E., 1843. Geology of the County of Londonderry and of parts of Tyrone and Fermanagh, Dublin.

Richter, R. and E., 1949. Die Trilobiten der Erdbach-Zone (Kulm) im Rheinischen Schiefergebirge und im Harz. 1. Die Gattung Phillibole. Senckenbergiana, xxx, 63-94.

SAlter, J. W., 1849. British Organic Remains, decade ii, pl. vii. Mem. Geol. Surv. U.K.

1853. Ditto, decade vii, pl. vi.

- 1864-1883. Monograph of British Trilobites. Palaeont. Soc.

Stubblefield, C. J., 1950. Remarks on Dr. Lamont's Interpretation of Features in the Trilobite Platycalymene. Geol. Mag., lxxxvii, 67.

WalcotT, C. D., 1908. Cambrian Geology and Palaeontology, No. 2. Cambrian Trilobites. Smithsonian Misc. Coll., liii, 13-52.

1910. Ditto. No. 6-Olenellus and other genera of the Mesonacidae. Ibid., liii, 231-422.

\section{RHYTHMIC LAYERING IN THE ULTRABASIC ROCKS OF RHUM}

SIR,-In the May-June number of the Geological Magazine, 1951, pp. 1668 , you publish a preliminary note on recent observations made by Professor L. R. Wager and Mr. G. M. Brown on the "Rhythmic Layering in the Ultrabasic Rocks of Rhum". I found this note of particular interest as 1 have been studying the petrology of the south-western part of Rhum, and in particular the harrisite, for the past two years.

According to Wager and Brown, the harrisite was built up from below ; and periods of upward growth of long, branching, coral-like olivines alternated with periods of precipitation and accumulation of discrete olivine 
grains. Referring to the layered structure, Wager and Brown note " that it will be possible to map individual sheets over wide areas much as a normal series of sedimentary rocks may be mapped ". Later they add : "we are satisfied that the fundamental characteristic of the Skaergaard intrusion, namely accumulation of material from the bottom upwards, is responsible also for the sheet structure of the Rhum rocks." This tacitly assumes that the stratigraphical sequence of the layers is identical with their time sequence, an assumption that cannot be made without the support of evidence based on a thorough investigation of all the contacts concerned. The authors illustrate their interpretation by a photograph of a vertical rock face (Plate VII). This photograph cannot be said to demonstrate the structure described at all clearly as it is the white material (plagioclase) which appears to branch more conspicuously than the grey (olivine). In my own experience. based on field observations and examination of many thin sections, I have found the branching material " growing up" from the base of each layer to be vein-like aggregates of plagioclase, not single crystals of olivine ; the olivine individuals are characteristically nearly equidimensional and subhedral. Throughout the harrisite the plexus of plagioclase veinlets is more resistant to weathering than the olivine and stands out on weathered surfaces in much the same way as granophyric net-veins in basic rocks and with a similar type of pattern. If there are coral-like olivine crystals in the harrisite, such as Wager and Brown describe, they must be quite exceptional ; so far, I have not seen any, though certain granular aggregates of olivine do locally simulate branching forms. Moreover, if Wager and Brown's postulated conditions had obtained, one would have expected an increasing tendency to idiomorphism in the olivines towards the upper part of each layer. In all the examples I have studied I have found no such tendency; the olivines are everywhere subhedral.

It should be pointed out that Harker long ago noticed the "coralline" structure of some of the layers. In the "Small Isles" Memoir, 1908, p. 75, he wrote: "Many of the rock-faces are pitted or even irregularly honeycombed, sometimes with cavities of rudely branching form. The salient parts often have forms resembling " concretionary growths in impure calcareous or calcareo-argillaceous sediments, or, when more elaborately developed, recall the shapes of sponges and corals. More remarkable structures arise when effects of this kind have been superposed upon a well-marked fine banding. Here we find structures comparable with a certain type from the Magnesian Limestone of Durham, in which the concretionary growth has not obliterated the original lamination." Harker's highly significant analogy serves to emphasize the extreme difficulty of the problem. In the "coralline ", layers of the Magnesian Limestone we know what the parental material was and yet have no convincing explanation to account for the structure. In the case of the layered peridotites of Rhum we do not know as yet what the parental material may have been, or even if there was any, other than a hypothetical magma. It is therefore not surprising that there is still no satisfactory explanation for these enigmatic structures.

GRANT INSTITUTE OF GEOLOGY,

George P. Black.

16th June, 1951.

WALL GRANGE BRICKYARD, STAFFS.

SIR,-Until recently there has been no definite proof of the age of the grit which caps the brick-pit at Wall Grange $\left(2 \frac{1}{2}\right.$-in. O.S. map, Sheet 33/95-963534), near Leek, Staffordshire. Walcot Gibson, in The Geology of the North Staffordshire Coalfields (1905, p. 30), suggested that it was First Grit and added that no goniatites or other marine organisms had been recorded in the underlying shales. The Survey Memoir on the Geology of the Country around Stoke-on-Trent $(1925$, p. 14) states that " grey, sandy, and marly shales lie directly beneath the First Grit and are underlain by dark 